\title{
鼻中隔原発髄外形質細胞腫例
}

\author{
中川 隆之 11 - 恵田 敏信 1$) \cdot$ 高島 忠義1) \\ 愛場 庸雅 2 ・ 中井 義明 2$) \cdot$ 上川 学3
}

\section{A Case of Extramedullary Plasmacytoma in the Nasal Septum}

\author{
Takayuki Nakagawa, Toshinobu Shigeta and Tadayoshi Takashima \\ (Yodogawa Christian Hospital)
}

Tsunemasa Aiba and Yoshiaki Nakai

(Osaka City University)

Manabu Uekawa

(Nogami Hospital)

\begin{abstract}
Extramedullary plasmacytoma, a rare type of plasmacytoma, can often be diagnosed only by histological examinations.

Recently, we encountered a case of extramedullary plasmacytoma originating in the nasal septum, which was diagnosed by immunohistochemical examination. The tumor was identified as IgG$\kappa$ type by the enzyme-labeled antibody technique. The tumor total removed with an Nd-YAG laser and post operative irradiation was performed. No signs of local recurrence or multiple myeloma have been recognized during the follow-up period.
\end{abstract}

Key words : extramedullary plasmacytoma, nasal septum, immunohistology

\section{緒 言}

形質細胞腫は, $\mathrm{B}$ 細胞の最終分化段階である形質細胞 に由来する腫瘍で，比較的稀な疾患である，骨䯣を原発 とする骨髄腫と軟部組織原発の䯣外形質細胞腫に大別さ れる. 䯣外形質細胞腫の頻度は，全形質細胞腫の約 $4 \%$ であり, 原発部位により異なった臨床経過をとり, 診断 や治療についても未解決の問題が少なくないとされてい る. 最近, 著者らは, 鼻中隔に発生し酵素抗体法にて $\operatorname{IgG}(\kappa)$ 型を呈した䯣外形質細胞腫の症例を経験したの で，文献的考察を加えて報告する.

\section{症例}

患者 : 75歳, 女性.
主訴 : 鼻閉感.

既往歷, 家族歷 : 特記事項なし。

現病歴: 平成 6 年 8 月頃より鼻閉感出現し, 徐々に悪 化したため, 近医耳鼻咽喉科を受診し, 両鼻腔にポリー プ様の腫瘤を指摘された。通院加療受けるる軽快せず, 同年11月 10 日当科紹介初診となる. 同年12月 1 日に生検 を行い, 血管腫の猃断のもと, 平成 7 年 1 月 6 日手術目 的に入院となった。

入院時局所所見：両側鼻腔に充満する灰白色で表面平 滑で柔らかい易出血性の腫瘤を認めた。腫瘤の一部には, 発赤を認めた. 口腔, 咽頭, 喉頭に異常所見を認めず, 頸部リンパ節の腫脹も触知しなかった.

画像所見：

1）淀川キリスト教病院耳鼻咽喉科

2) 大阪市立大学医学部耳鼻咽喉科学教室

3）野上病院耳鼻咽喉科 
単純X線所見; 両側鼻腔に陰影を認め, 節骨洞拉よび 上顎洞にも陰影を認めた。

造影 CT 所見; 固有鼻腔に増強される腫瘤を認め, 骨 浸潤は, 著明でなく, 腫瘤は, 鼻中隔を中心として, 圧 排性の発育像を呈していた。腫瘤の前端之後端は，鼻中 隔に移行していた(図 1).

MRI 所見；ガドリミウムにより不均一に増強される 腫瘤が固有鼻腔に認められた。眼窩执よび頭蓋内への浸 潤をらかがわせる所見は認められなかったが，節骨洞拉 よび上顎洞は圧排され，その容積の著明な縮小が観察さ れた(図 2)。これらの画像所見から，鼻中隔原発の腫瘍 性病変が考觉られた。

尿，血液検查所見：血清蛋白を含め，特記すべき異常 所見を認めなかった。

臨床経過：血管腫の診断のもと, 平成 7 年 1 月 9 日全 身麻酔下に外鼻切開を加光, 経鼻的に腫瘍摘出術を施行 した. 腫瘍は, 鼻中隔前端部から後端部にかけて存在し て扮り，前端部执よび上方には正常粘膜と考兄られる部 分が認められた．前方，上方は，この正常粘膜部で切断 し, 後方は口蓋粘膜を含めて切除し，下方は鼻腔底にて 切断した(図 3 )。さらに，摘出創縁をNd-YAG レーザー にて焼灼した。

病理組織所見 : 摘出腫瘍は, 大小不同の多角形の細胞 より構成されて扮り,これらの細胞間に小リンパ球の浸 潤が著明に認められた。ギムザ染色で胞体が濃染し，核

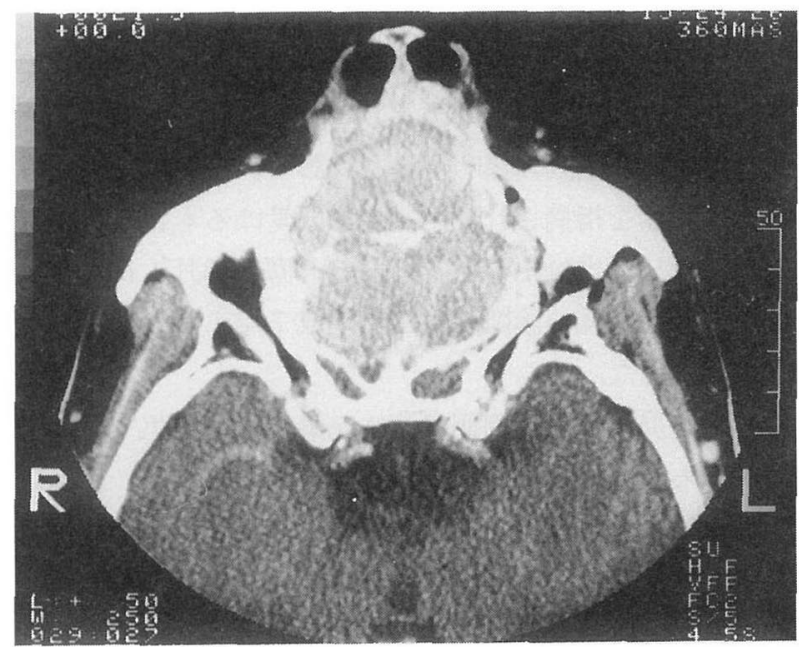

図 1 造影 CT 所見

固有鼻腔に増強を受ける腫瘤が認められる，骨浸潤は明 らかでなく，圧排性の発育が認められる。

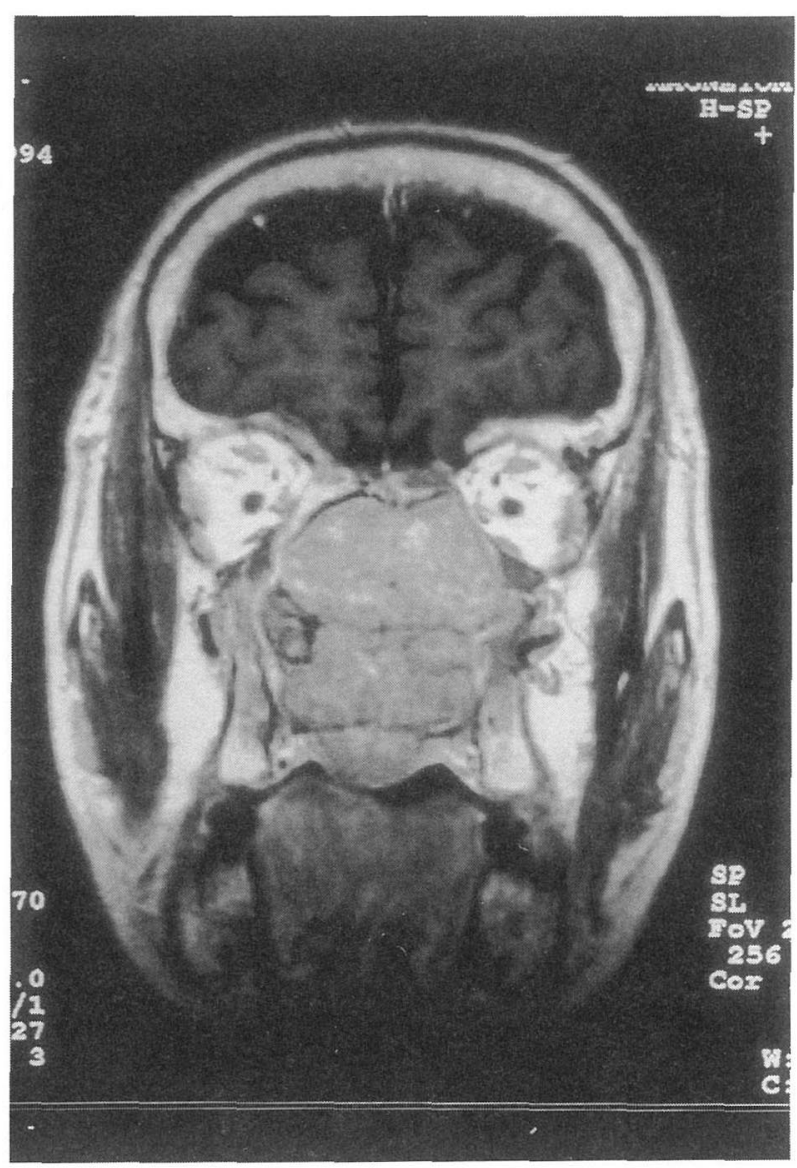

図 2 ガドリミウム造影 $\mathrm{T}_{1}$ 強調 MRI 所見 ガドリミウムにて不均一に増強される腫瘤が固有鼻腔に 認められる。

周明庭が認められ，形質細胞腫が強く疑われた(図 4). 免疫組織化学的には, 胞体に $\operatorname{IgG}(\kappa)$ がモノクロナルに 染色され, 形質細胞腫と診断された(図 5 )。な掠, 摘出 標本の断端に腫瘍組織の残存は認められなかった.

術後検查所見 : 形質細胞腫の診断が得られたため, 直 らに全身的検索を行った。骨执よびガリウムシンチに異 常所見は認められず，骨䯣生検に执いても異常所見は認 められなかった。ささらに, 血清 $I g$ を含め血液検查所見 に異常を認めず，尿中 B-J 蛋白も陰性であった．以上の 所見から，鼻腔䯣外形質細胞腫と診断された。

術後経過：平成 7 年 1 月 27 日上り 3 月 2 日に局所にリ ニアック $50 \mathrm{~Gy}$ の照射を行い, 同年 3 月 23 日退院し, 現在外来にて経過観察中であるが, 血液, 尿検查所見, 局 所，所属リンパ節括よび全身所見に異常を認めていない。 


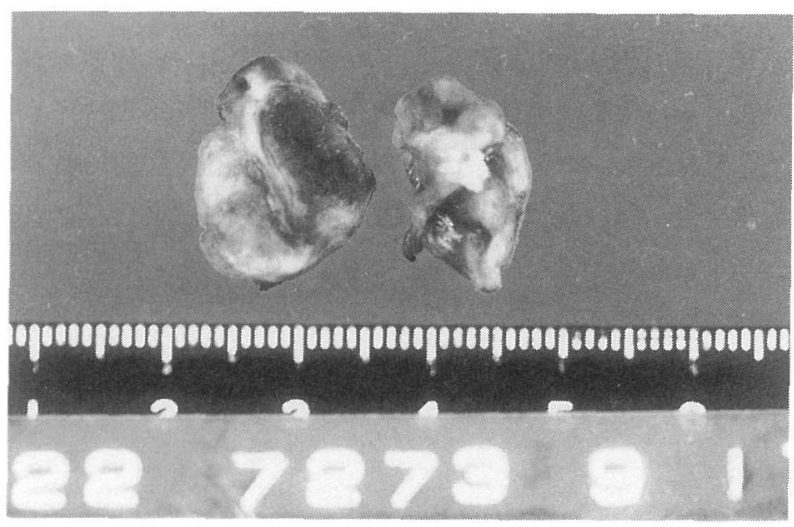

図 3 摘出標本

$20 \times 13 \mathrm{~mm}$ 弾性軟, 灰白色の腫瘤で腫瘤内に出血を認 める.

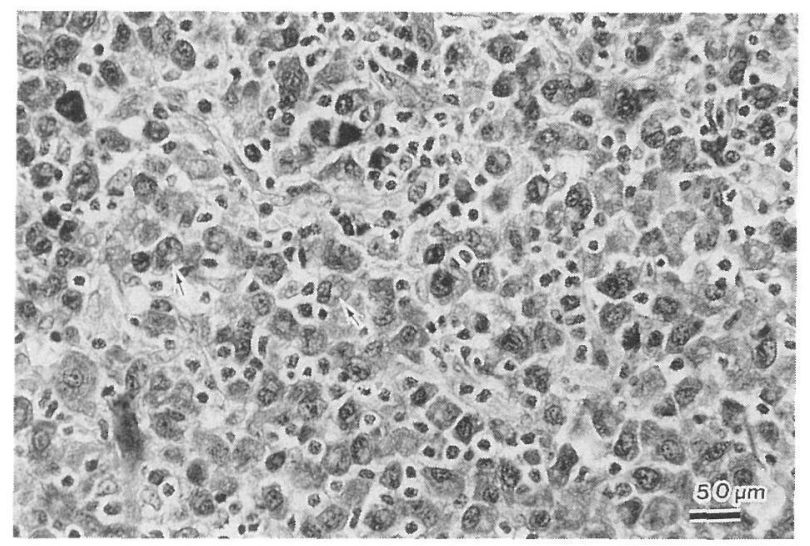

図 4 病理組織所見(ギムザ染色)

大小不同の細胞から構成されて括り, 細胞質は濃染され, 核周明庭(矢印)が認められる。

\section{考察}

1. 分 類

形質細胞腫は，臨床的分類には一般にWillis ら 1$)$ の分 類が用いられて扣り, 多発性骨䯣腫, 弧発性骨䯣腫, 䯣 外形質細胞腫の 3 つに分類されている. 多発性骨骨道腫は, 全身骨，特に凖椎，骨盤骨，頭蓋骨に骨破壊を呈し，血 清蛋白異常, 尿中 B-J 蛋白の出現を認め, $1 \sim 3$ 年で死 に至る全身的疾患である。弧発性骨髄腫は，骨に単発性 の病変を認めるが, 全身性の骨病変を否定でさるもので あり, 多発性骨䯣腫に移行する可能性が高いとされてい る. 䯣外形質細胞腫は, 骨髓以外の軟部組織から発生し

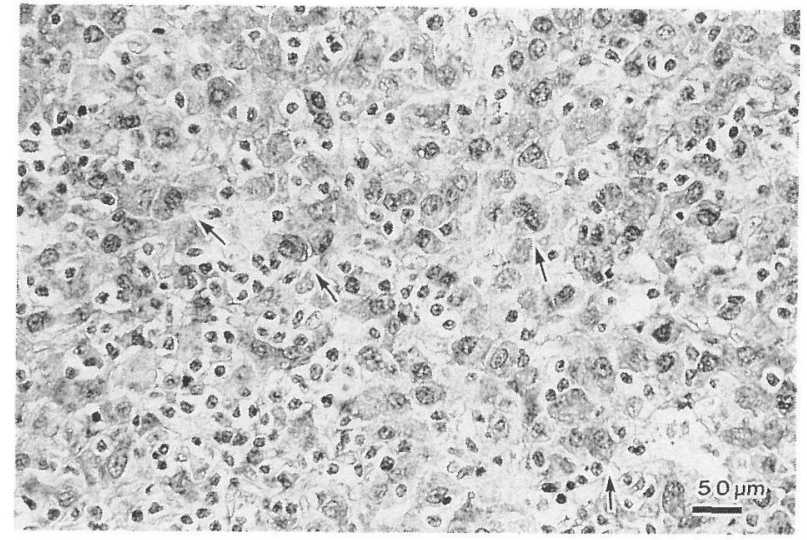

図 5 免疫組織所見

細胞質に $\operatorname{IgG}(\kappa)$ 陽性所見(矢印)を認める。

たものであり，本例は，全身的骨の検索にて異常所見が 認められなかったことから，䯣外形質細胞腫と考㝋られ た。

2. 発生頻度特よび部位

䯣外形質細胞腫の形質細胞腫に占める割合は，約 $4 \%$ と報告されている2)。また, 䯣外形質細胞腫の発生頻度

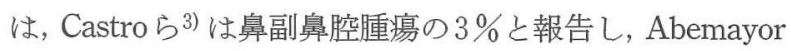
ら 4 は, 上気道悪性腫瘍の $0.4 \%$ 之報告して和り, 耳鼻 咽喉科領域では稀な疾患とい觉る。䯣外形質細胞腫の発 生部位としては，頭頸部領域が多いことが知られて拉 り, Batsakis ${ }^{5)}$ は約 $80 \%$ とている。また, Poole ら6) は, 頭頸部領域の約 $20 \%$ が鼻副鼻腔原発と報告している. 本邦に扣ける報告では, 松永ら ${ }^{7)}$ は, 頭頸部領域のらら 約 $40 \%$ が鼻副鼻腔原発とし，元井 ${ }^{81}$ は，約 $20 \%$ と報告 して持り, 䯣外形質細胞腫は頭頸部, 特に鼻副鼻腔が好 発部位であると考えられる。䯣外形質細胞腫の性比は, 男性に多い傾向が認められ3), 好発年齢は， 50～70歳代 とされている9)。したがって，中高年の鼻副鼻腔腫瘍に 扣いて, 髄外形質細胞腫を念頭に执く必要があると考光 られる。

3. 診断と治療

䯣外形質細胞腫では, 血清蛋白, 尿中 B-J 蛋白, 血清 カルシウム, 骨の検索で異常所見を認めることは稀で8), 病理組織検査で診断され，免疫組織化学的検索を要する 場合が多い. M蛋白血症を示吉疾患のうち, 髄外形質細 胞腫の占める割合は低く10), 陽性になるのには, 腫瘍重 量 $10 \mathrm{~g}$ 以上が必要とされている11). 画像診断について 
は，CT では，骨破壊をともなわない，膨張性の発育が 主であるといら報告12) も認められるが，明らかに特徵 的とされる画像所見は乏しい13). 病理組織学的診断むま た容易ではなく，本例と同様に生検で確定診断を得られ ない場合も報告されている14)。形質細胞の腫瘍性増殖は， 組織化学的にモノクロナルな免疫グロブリンの産生を証 明することで確定され8)，血清中に異常を認めない症例 では, 免疫組織化学的検討が必要となる15). 免疫組織化 学的には，軽鎖 $\kappa, \lambda$ のいずれかが，モノクロナルに陽 性となる8)。本例では, 酵素抗体法にて $\operatorname{IgG}(\kappa)$ が腫瘍 細胞胞体内に認められ，形質細胞腫の診断が得られた。

治療法については, 手術単独, 手術と放射線の併用が

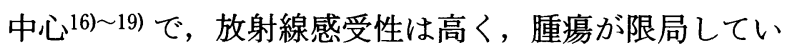
た場合は，放射線療法の久で良い結果が得られた症例も 報告されている20)。 屯た，化学療法の有効性も報告され ており2), 血中免疫蛋白の異常例で用いられることが多 い. 本例では, 術前診断が血管腫であったため, 術前放 射線照射を行っていないが，腫瘍摘出術後に Nd-YAG レーザー焼灼を行い, 術後 $50 \mathrm{~Gy}$ の放射線照射を行っ た. 腫瘍の大きさから考えて，いずれにせよ外科的療法 は必要であったと考兄られる.な报, 現在のところ再発 をらかがわせる兆候は認めていない。

\section{4. 予 後}

多発性骨䯣腫の予後は, 平均 $1 \sim 2$ 年とされているが, 䯣外形質細胞腫の予後は, 比較的良好で, 5 年生存率は 50〜70\%とされている29)21). 䯣外形質細胞腫においても 多発性骨髄腫への移行が報告されており 14)22)，多発性骨 髄腫への移行が予後を左右すると考えられ，細胞の分化 度が低い症例が移行しやすいとされており22233，細胞の 分化度が臨床経過に差異をもたらしている可能性が考兄 られる。しかしながら，多発性骨䯣腫への移行を予測し らるマーカーは現在のところ明らかにされていない。さ らに，髄外形質細胞腫が多発性骨䯣腫の一部分症とする 報告24) や多発性骨䯣腫の約 $70 \%$ は䯣外形質細胞腫の形 式で発症するとの報告もあり25)，厳重な経過観察が必要 であると考えられる. 大塚ら ${ }^{15)} は$ ，覀性リンパ腫に準じ た経過観察を推奨している．また，先述のごとく髄外形 質細胞腫は頭頸部領域に好発することからも，初診に当 たることの多い耳鼻咽喉科医が䯣外形質細胞腫を念頭に 扣いて診療に望むことが重要であると考えられる。

\section{まとめ}

腫瘍摘出術に Nd-YAG レーザーを用い，術後放射線 照射を行った鼻中隔原発の䯣外形質細胞腫の 1 例につい て臨床経過を述べるとともに若干の文献的考察を加えて 報告した。な拈，本症例は現在まで再発の兆候は認めら れていない。

な拈，本論文の要旨は，第253回日本耳鼻咽喉科学会大阪地 方連合会にて発表した。

\section{文献}

1) Willis RA : Plasmacytomas and myelomatosis. Pathology of Tumors 4th ed. pp 795 802, Butterworth, London, 1967.

2) Wiltshow E : The natural history of extramedullary myeloma of bone and myelomatosis. Medicine $55: 217 \sim$ 238, 1976.

3 ) Castro EB, Lewis JS and Strong EW : Plasmacytoma of paranasal sinuses and nasal cavity. Arch Otolaryngol 97 : 326 329, 1973.

4 ) Abemayor E, Canalis RF, Greenberg P, et al : Plasma cell tumor of head and neck. J Laryngol Otol $17: 376 \sim 382$, 1988.

5 ) Batsakis JG : Plasma cell neoplasms in the head and neck. Tumors of the Head and Neck 2nd editions. pp 471 475, Williams \& Wilkins, Baltimore, 1979.

6 ) Poole AG and Marchetta FC : Extramedullary plasma cytoma of the head and neck. Cancer $22: 14 \sim 21,1968$.

7 ) 松永信也, 前山拓夫, 島 哲也, 他 : 頭頸部領域に原発し た髄外形質細胞腫の 3 症例. 耳鼻臨床 $80: 257 \sim 265,1987$.

8 ) 元井 信, 万代光一, 山上啓太郎, 他 : 䯣外形質細胞腫 一症例報告と本邦報告例の統計的分析一. 病理と臨床 9 ： 1077 1082, 1991.

9 ) Knowling MA, Harwood AR and Bergsagel DE : Comparison of extramedullary plasmacytomas with solitary and multiple plasma cell tumor of the bone. J Clin Oncol $1: 255 \sim 262,1983$

10) Kyle RA and Lust A : Monoclonal gammanopathies of undetermined significance. Semin Hematol $26: 176 \sim 200$, 1989

11) Salmon $\mathrm{SE}$ and Smith $\mathrm{BA}$ : Immunogloburin synthesis and total body tumor cell number in IgG multiple myeloma. J Clin Invest $49:$ 1114 1121, 1970.

12) Cumbo V, Galina G, Messina $P$, et al : Extramedullary plasmacytoma of the maxillary sinus ; report of a case. J Oral Maxillofac Surg $46:$ 406 409, 1988.

13）白石昭彦, 箕輪興仁, 桑島賢介, 他 : 鼻 - 副鼻腔原発髄外 
形質細胞腫の 3 症例. 画像診断 $13: 105 \sim 110,1993$.

14）今村俊一, 菊島一仁, 白倉真人, 他: 多発性骨䯣腫へ移行 した鼻髄外形質細胞腫例. 耳鼻臨床 $85: 1796 \sim 1775,1992$.

15）大塚 亮, 近田真人, 藤井 了, 他: 鼻腔原発䯣外形質細 胞腫の 1 例. 臨床血夜 $29: 2091 \sim 2095,1988$.

16) Corwin $J$ and Lindberg RD : Solitary plasmacytoma of bone vs extramedullary plasmacytoma and their relationship to multiple myeloma. Cancer $43: 1007 \sim 1013,1979$.

17) Harwood $\mathrm{AR}$, Knowring $\mathrm{MA}$ and Bergsagel $\mathrm{DE}$ : Radiotherapy of extramedullary plasmacytoma of the head and neck. Clin Radiol 32 : 31 36, 1981.

18) Gaffeny CC, Dawes PJDK and Jackson D : Plasmacytoma of the head and neck. Clin Radiol 38 : 385 388, 1987.

19) Greenberg P, Paker RG, Fu YS, et al : The treatment of solitary plasmacytoma of bone and extramedullary plasmacytoma. Am J Clin Oncol 10 : 199 204, 1987.

20) Medini E, Rao $Y$ and Levitt SH : Solitary extramedullary plasmacytoma of upper respiratory and digestive tracts. Cancer $45:$ 2893 2896, 1980.
21) Webb HE, Harrison EG, Masson JK, et al : Solitary extramedullary plasmacytoma of the upper part of the respiratory tract and oropharynx. Cancer $15: 1142 \sim 1155$, 1962.

22) Meis JM, Butter JJ, Osborne BM, et al : Solitary plasmacytomas of bone and extramedullary plasmacytomas. Cancer 59 : 1475 1485, 1987.

23）深本克彦, 杉田麟也：鼻副鼻腔原発の髄外形質細胞腫の 2 例. 耳鼻臨床 $83: 729 \sim 734,1990$.

24) Levin HS and Mostifi FK : Symptomatic plasmacytoma of the testis. Cancer $25: 1193 \sim 1203,1970$.

25) Hayes DW, Bennett WA and Frank JH : Extramedullary lesions in multiple myeloma. Arch Pathol 53 : 262, 1952.

$$
\left(\begin{array}{l}
\text { 原稿受付 : 平成 } 7 \text { 年 } 7 \text { 月 } 10 \text { 日 } \\
\text { 原稿採択 : 平成 } 7 \text { 年 } 8 \text { 月 } 9 \text { 日 } \\
\text { 別刷請求先 : 中川隆之 } \\
\text { †533 大阪市東淀川区淡路2-9-26 } \\
\text { 淀川キリスト教病院耳鼻咽喉科 }
\end{array}\right)
$$

